\title{
Do "HIV-profecia" ao "HIV-território": um estudo de caso sobre juventude, subjetividade e ativismo em HIV/aids
}

\author{
$\mathrm{I}^{1}$ Lucas Pereira de Melo, ${ }^{2}$ Marina Gruenwald Peres, \\ ${ }^{3}$ Jared Wanderson Moura de Sousa, ${ }^{4}$ Lumena Cristina de Assunção Cortez I
}

Resumo: Neste artigo aborda-se iniciativas individuais e coletivas de jovens ativistas em HIV/aids e seus desdobramentos na produção de subjetividade. Teve-se como objetivo compreender os significados do engajamento no movimento social de aids e suas inflexóes na produção do jovem vivendo com HIV/aids, a partir da experiência de um interlocutor. Trata-se de estudo de caso integrante de etnografia sobre experiências de pessoas vivendo com HIV/aids que vivem no interior do Rio Grande do Norte, feita com 17 interlocutores diagnosticados há mais de um ano. Dois motivos nortearam a seleçấo do caso: ser jovem com uma experiência construída em torno de eixos de diferenciação e de enunciação de si e por ter demonstrado inserçâo como ativista. As informaçôes foram obtidas mediante entrevistas semiestruturadas e observação participante. Por meio de análise contextual, integrada e relacional, a arte como linguagem política do ativismo em HIV/aids se colocou com possível de transformar um "vírus-profecia", maldição que espreita homens gays, em um "vírus-território", lugar de acessos a cuidado em saúde, afetos, trocas e experiências de alteridade. Por fim, destaca-se como a relação entre arte e ativismo em HIV/ aids permite a produção de narrativas positHIVas que se colocam como uma Sociologia das Ausências.

> Palavras-chave: HIV/aids; experiência com a enfermidade; ativismo político; arte; minorias sexuais e de gênero; geração; subjetividade.

\author{
1 Universidade de São Paulo. \\ Ribeirão Preto-SP, Brasil \\ (Ipmelo@usp.br). \\ ORCID: 0000-0001-8392-1398 \\ 2 Universidade de São Paulo. \\ Ribeirão Preto-SP, Brasil \\ (mgperes29@gmail.com). \\ ORCID: 0000-0001-5889-4914 \\ ${ }^{3}$ Universidade Federal do Rio \\ Grande do Norte. Natal-RN, Brasil \\ (jared.ifrn@hotmail.com). \\ ORCID: 0000-0003-3673-4658 \\ ${ }^{4}$ Universidade de São Paulo. \\ Ribeirão Preto-SP, Brasil \\ (lumena@usp.br). \\ ORCID: 0000-0002-4652-6556
}




\section{Introdução}

Em julho de 2019, a revista Trip publicou a matéria "O núcleo macio da aids", de Nathan Fernandes'. O texto apresentava produçóes artísticas de um grupo de jovens ativistas que encontraram na arte uma forma de provocar, acolher, informar, sensibilizar, fazer pensar e construir outras narrativas sobre o vírus da imunodeficiência humana e a síndrome da imunodeficiência adquirida (HIV/aids). O "núcleo macio" que toma lugar desde o título faz referência ao texto de Plínio Marcos, O Ator, citado por um dos artistas entrevistado por Fernandes. De acordo com Marcos:

"Bendito seja quem souber dirigir-se a esse homem que se deixou endurecer, de forma a atingi-lo no pequeno núcleo macio de sua sensibilidade, e por aí despertá-lo, tirá-lo da apatia, essa grotesca forma de autodestruição a que, por desencanto ou medo, se sujeita, e por aí inquietá-lo e comovê-lo para as lutas comuns da libertação"².

O ponto central da matéria é problematizar e publicizar iniciativas individuais e coletivas de jovens artistas soropositivos que fazem da arte uma linguagem política, o que no campo do HIV/aids é de fundamental importância por se tratar de uma epidemia de significados (TREICHLER, 1987) envolta, nas últimas décadas, por uma restriçáo discursiva (INÁCIO, 2016). A despeito da restrição discursiva na atualidade como consequência da cronificaçáo da infecçáo pelo HIV e seus tributos aos desenvolvimentos biomédicos, políticos e sociais, Inácio (2016) chama atenção a reconstrução do HIV/aids, hodiernamente, como uma doença segredo. Se considerarmos a aids como uma "epidemia de significados", como propôs Treichler (1987), podemos aventar que a produção de zonas de silêncio e de segredo em torno do viver com HIV/aids (e da epidemia em si) se dá não como um arrefecimento do "seu enorme poder de gerar significados" (p. 32), uma vez que as pessoas que vivem com HIV/aids (PVHA), na intimidade de seus corpos e relaçôes sociais, permanecem "ouvindo os gritos altos" estruturados e estruturantes dessas narrativas que seguem em disputa.

Nesse sentido, a matéria de Fernandes aborda uma forma de ativismo já consagrada desde os primórdios da epidemia, cujas estratégias visam impactar o embrutecimento desse "núcleo macio" produzido pelo pânico moral em torno do HIV/aids. Em seu artigo sobre o pânico moral produzido no Brasil a respeito do casamento gay nos anos 2000, Miskolci (2007) aborda o pânico moral como um conceito que 
explica o temor e o medo social enervantes de reaçóes coletivas às mudanças ou identidades sociais, nomeadamente as que emergem de forma repentina, sentidas como perigosas e ameaçadoras à manutenção da ordem social e de seus padróes normativos. Dessa forma, o pânico moral busca restabelecer e renegociar os limites morais da sociedade por meio de estratégias de controle social. Além disso, o pânico moral, geralmente, é erigido em torno da produção de significados não associados ao "real", pois "chamam a atenção para um assunto, porque ele representa, na verdade, outra questão” (MISKOLCI, 2007, p. 114). No caso do pânico moral em torno do HIV/aids, um de seus principais "alvos" foram (e continuam sendo) as orientaçôes e as práticas sexuais dissidentes com o objetivo central de manter a família nuclear tradicional e as demais instituições e papeis sociais que a sustenta.

Voltando ao texto de Fernandes, em nossa análise o jornalista expóe uma gramática política engendrada no entrelaçamento entre arte e ativismo em HIV/aids e na intersecção entre marcadores sociais da diferença, como geração, gênero, classe social, sexualidade, soropositividade e raça. É contra esse pano de fundo que este artigo se inscreve, pois apresentamos aqui a história de Franco Fonseca ${ }^{3}-$ um jovem negro, 24 anos de idade, gay, com curso universitário, artista, residente em Natal (capital do Rio Grande do Norte, no Nordeste brasileiro), oriundo de um município de pequeno porte do interior do estado, classe média de origem popular e que vive com HIV/aids desde 2015.

No universo de uma etnografia mais ampla, a história de Franco nos chamou a atenção dado o atual perfil epidemiológico da epidemia no Brasil, que aponta o aumento da incidência da infecção pelo HIV entre jovens. Do ano de 2007 a junho de 2019, a maioria dos casos de infecção pelo HIV encontrava-se na faixa etária de 20 a 34 anos, com percentual de 52,7\% dos casos (BRASIL, 2019). É neste contexto que a maior participação dos "jovens vivendo com HIV/aids" (JVHA) no movimento social de aids e em outros espaços de militância e ativismo político tem chamado a atenção das ciências sociais, não para averiguar os meandros epidemiológicos da epidemia, mas por permitir o estudo da maneira como o Estado, via política de saúde, e a biomedicina, por meio de seus regimes terapêuticos, produzem identidades (CUNHA, 2018). Mais que isso, o engajamento e a gramática política dos JVHA, no cenário mais amplo do movimento social de aids, constituem arenas privilegiadas para compreender as relaçôes entre geração, sociedade civil e práticas estatais. Assim, através da criação de redes e encontros de jovens, tem-se destacado iniciativas 
individuais e/ou coletivas que recolocam a aids e a experiência com o HIV no espaço público, a partir de narrativas biográficas como formas de engajamento político (CORTEZ, 2019; SIMÓES, 2018).

No Brasil, o ativismo em HIV/aids, inicialmente caracterizado por uma forte e coordenada atuação das organizaçôes não governamentais (ONG-Aids), funcionou como mediador entre tais entidades, PVHA, profissionais de diversas áreas, agentes estatais e pesquisadores na luta por solidariedade e pela defesa de direitos (VALLE, 2016; 2017a). Cabe salientar o caráter pioneiro do movimento social de aids brasileiro, pois não só congregou atores, instituiçôes e setores sociais distintos, como também mobilizou e promoveu a visibilidade pública da epidemia, construindo-a como um problema político (SILVA, 1999; GALVÃO, 2000; SEFFNER; PARKER, 2016). Além disso, destaca-se o papel dos militantes ligados ao então denominado movimento homossexual tanto na criação das ONG-Aids quanto na formulação de programas governamentais de controle e prevenção da doença (FACCHINI, 2005; SIMÓES, 2018).

As etnografias sobre ativismo em HIV/aids feitas no Brasil têm evidenciado outros aspectos, além das práticas de mediação na arena política, relativos à experiência das PVHA. Tais estudos chamam a atenção para as relaçôes entre ativismo e subjetividade, uma vez que o engajamento no movimento social permite ao indivíduo a produção de estratégias de ajuda mútua; o compartilhamento de saberes e experiências sobre doença, sexualidade, direitos humanos, política de saúde, gênero; a sociabilidade, permeada pela construção de afetos e vínculos inclusive entre mundos sociais distintos (diferenças de classe social e lugar de moradia, por exemplo); e a produção de identidades (PELÚCIO, 2007; PELÚCIO; MISKOLCI, 2009; VALLE, 2008; 2015; 2017b; NELVO, 2018).

É nessa perspectiva que pretendemos abordar o ativismo em HIV/aids, uma vez que tivemos como objetivo compreender os significados do engajamento no movimento social de aids e suas inflexôes na produção de subjetividades específicas, como a dos JVHA, a partir da experiência de Franco. Ou seja, buscamos analisar não a atuação política dos ativistas em arenas institucionais, mas os aspectos mais particulares que permitem investigar seus desdobramentos na produção de subjetividade. Nesse sentido, questionamos de que forma o engajamento de JVHA como ativistas da aids modela suas experiências e identidades. 


\section{Metodologia}

Este estudo de caso qualitativo faz parte de uma etnografia mais ampla sobre a experiência de PVHA, ativistas ou não, que residiam em municípios do interior do Rio Grande do Norte, ou seja, trazia como uma das problemáticas da pesquisa a questáo dos contextos descentrados, fora dos grandes centros urbanos, cujo trabalho de campo foi conduzido entre 2017 e 2019 e envolveu, além do coordenador, estudantes de graduação e de pós-graduação. A pesquisa foi aprovada pelo Comitê de Ética em Pesquisa da universidade conforme parecer no 1.947.922/2017, em consonância com a Resolução no 510/2016 do Conselho Nacional de Saúde.

O estudo de caso se colocou como opção metodológica, pois pretende erigir um saber em torno da particularidade individual, reconhecendo, na singularidade da experiência do sujeito, o espaço privilegiado onde a cultura e a história se articulam e constroem algo comunicável. Portanto, a centralidade deste desenho metodológico é, certamente, a individualidade, porém, não entendida como uma abstração, mas sim como uma conquista criativa, sempre discursivamente estruturada, historicamente contextualizada e socialmente produzida (SERRANO BLASCO, 1997; STAKE, 2000; BAŠKARADA, 2014).

Interpretar a particularidade da existência humana por meio de narrativas produzidas por um sujeito permite integrar o plano individual ao cultural. No plano individual, os sujeitos utilizam os instrumentos necessários para organizar sua vida em episódios significativos e, no plano cultural, a narrativa possibilita articular e compartilhar crenças e valores, além de pôr a história do narrador em diálogo com outras histórias e com o contexto sociocultural que lhes dá sentido (SERRANO BLASCO, 1997).

O caso apresentado aqui foi extraído do universo de 17 entrevistados no mencionado estudo (amostragem intencional, não probabilística), selecionando-o pelos seguintes motivos: ser jovem com uma experiência construída em torno de eixos de diferenciação e de enunciação de si, como destacado na introdução, e por ter demonstrado inserção como ativista em HIV/aids. Conhecemos Franco em 2017, durante um seminário de pesquisa sobre gênero, sexualidade e HIV/aids, no qual ele apresentou, junto com outros colegas, uma peça teatral sobre essa temática. Com o contato e a convivência durante o período do evento, lhe contamos sobre a pesquisa que estávamos conduzindo e do nosso interesse em sua participação como um de 
nossos interlocutores. $\mathrm{Na}$ semana seguinte ao evento, uma das pesquisadoras e ele trocaram mensagens por WhatsApp e marcaram a primeira entrevista em Natal, cidade onde ele residia.

A primeira entrevista foi em 2017 num pátio próximo à biblioteca central e a segunda em 2018, realizada por outro pesquisador que também mantinha interlocuçôes com Franco numa cafeteria - ambas localizadas no campus de uma universidade. No primeiro encontro foram apresentados a Franco os objetivos da pesquisa, sua forma de realização e os aspectos éticos envolvidos. Em seguida, foi solicitada a anuência para participaçáo no estudo por meio da assinatura do Termo de Consentimento Livre e Esclarecido. Cada entrevista durou aproximadamente 90 minutos, foram orientadas por um roteiro com tópicos-guia, registradas em áudio e transcritas na íntegra. A técnica de análise de dados empregada foi a codificação temática (FLICK, 2009). Sendo assim, procedeu-se a codificação aberta e depois a seletiva para a produção de um sistema de categorias que abarcasse os conceitos e códigos presentes nas narrativas de Franco. Por fim, os itens e variaçôes nas categorias encontradas foram analisados, buscando interpretar seus significados e estabelecer a relevância das variaçôes e das próprias categorias para a narrativa como um todo.

\section{Franco e um "vírus-profecia"}

Franco nasceu em um município localizado na região da Costa Branca do Rio Grande do Norte, distante $175 \mathrm{Km}$ da capital. Com uma população de aproximadamente 32 mil habitantes, o município se destaca pela produção de sardinhas, sal marinho e petróleo. Ele saiu da casa dos pais para morar em Natal em 2013, ano em que ingressou na universidade para realizar seu curso de graduação em Artes Cênicas.

Quando realizamos a primeira entrevista, Franco cursava seu último ano de graduação e, no nosso segundo encontro, estava no mestrado na mesma universidade. Em 2018, ele havia deixado de trabalhar como professor contratado em uma escola pública devido à concessão da bolsa de mestrado e morava em uma casa junto com seu pai adotivo e seu irmão ${ }^{4}$.

As redes de apoio de Franco se construíam com muitas linhas, mas algumas delas eram "linhas de frente", como o HIV/aids. Ele realizou o teste rápido anti-HIV em dezembro de 2014, depois de ter pedido a um dermatologista para averiguar se estava com sífilis. Com alguma insistência, o médico solicitou os exames. O teste rápido 
anti-HIV foi realizado na unidade de saúde da família (USF) na cidade onde nasceu. Franco tinha ido passar as festividades de final de ano com a família biológica. Todavia, a enfermeira da USF não lhe informou o resultado e solicitou um exame laboratorial para confirmação.

A enfermeira não me disse, não sei por qual motivo, que o diagnóstico tinha dado positivo e me encaminhou para a coleta de sangue. Como eu já sabia que o procedimento de coletar sangue era porque tinha dado positivo, eu já fiquei na noia. Mas pensei: "ah, é falso positivo!" A gente tem essa expectativa. Então, em 26 de dezembro, meu exame chegou lá no interior, só que eu não tinha como ir buscar porque era natal e também porque toda a minha família tinha vínculos com o posto. Então eu deixei pra buscar em janeiro. Aí li "reagente"!

O embaraço de enfermeiros em comunicarem o resultado do teste anti-HIV tem sido registrado na literatura. De acordo com Araújo et al. (2018), apesar dos avanços tecnológicos no diagnóstico e manejo de PVHA, enfermeiros relataram dificuldade de realizar o aconselhamento pós-teste, principalmente quando o resultado é positivo. Além disso, a maioria dos participantes do estudo disseram não se sentir seguros na realização do teste rápido e nem no aconselhamento pós-teste, sendo esta última ação considerada a mais complexa (ARAÚJO et al., 2018).

$\mathrm{Na}$ experiência de Franco, receber o diagnóstico reagente para o HIV o deixou confuso, apresentando também sentimentos como culpa e medo da morte.

Fiquei muito confuso... Pedi esses exames com muita segurança, achando que não iriam dar positivos. Quando recebi o resultado, peguei a mochila que eu estava e voltei para Natal. Eu não aguentei ficar lá. Chegando em Natal, liguei para uma amiga, contei o que tinha acontecido, porque, volto a dizer, a enfermeira não me disse que tinha dado positivo, ela me falou depois, via WhatsApp, porque ela me deu o telefone dela. A bichinha... despreparada total. E aí, as narrativas comuns de que sua vida vai acabar, que você vai morrer a partir dali.

A motivação para solicitar os exames ao médico era a suspeita de ter adquirido sífilis de seu parceiro. A única certeza que ele tinha era essa. Inclusive disse que não podia afirmar que "pegou" o HIV na relação sexual com esse rapaz e que a decisão de fazer sexo sem camisinha também foi escolha dele. Após a descoberta do diagnóstico, Franco foi procurar esse rapaz para conversar sobre a situação, mas ele "sumiu". Só se reencontraram, casualmente, anos depois, na fila da farmácia do serviço especializado onde retiravam mensalmente as "jujubas" - expressão popular entre PVHA, principalmente jovens, para se referir aos medicamentos da terapia antirretroviral (TARV). 
Esses aspectos no momento pós-diagnóstico foram ladeados pela agregação de estigmas com a chegada do HIV em sua vida:

O que mais me incomodou foi saber que eu ia ter mais um estigma, porque eu já tinha
o estigma de ser gay afeminado, vir da zona rural, ser bicha, pobre, parda, preta, como
queiram me identificar, e agora tenho o estigma do HIV. E ainda sou artista. Então eu
fiquei pensando: "Porra! Tudo que profetizaram para minha vida, quando eu era criança,
aconteceu!" Diziam: "você é gay" logo "você vai ter isso". Parece que já ia acontecer, já era
uma maldiçáo que já estava certa, que já estava colocada no meu caminho de uma forma
ou de outra. Então, assim, a sensação foi de muita culpa e medo de morrer. (grifos nossos)

Na interpretação de Franco, o advérbio "já" circunscrevia o duplo caráter do "HIVprofecia”: um vírus onipresente e inexorável. O HIV/aids como "uma maldição que já estava certa" não se coloca aqui como um destino que espreita, a cada esquina, os jovens gays, mas, sim, como parte de um processo mais amplo, no qual a exposição ao HIV se materializa nas franjas de forças sociais e políticas que modelam experiências sociais. Essa afirmação nos levou a dialogar com Scott (1998, p. 304) quando a autora adverte que "não são indivíduos que têm experiência, mas sim os sujeitos que são constituídos pela experiência". Ou seja, devemos nos indagar: como se estruturam e operam experiências sociais, historicamente construídas, capazes de vulnerabilizar os sujeitos que se constituem a partir delas? Com isso, deslocamos o eixo analítico das identidades como auto-evidentes, das diferenças como naturais para a historicidade da experiência e das identidades que ela produz (SCOTT, 1998), o que nos permite compreender o duplo caráter do "HIV-profecia" como sendo socialmente construído e não como atributo inerente ao sujeito, como salientado por Franco.

Ao narrar as relações viscerais entre "profecias", "maldiçôes" e estigmas atrelados ao HIV/aids, Franco parte da perspectiva de seus interlocutores - notadamente familiares, mas também pessoas próximas - o que lhe permitiu desnudar as representaçôes (talvez inclusive dele, num primeiro momento) ainda fortemente associadas à aids e às pessoas acometidas. Porém, ele aprofunda a questão quando pôs duas categorias do mundo cristão (muitos de seus familiares são evangélicos pentecostais) ao lado de uma categoria social. Como a reconstrução narrativa é um momento em que a pessoa entrelaça temporalidades diversas (WILLIAMS, 1984), no momento da nossa entrevista, Franco já parecia ter percorrido uma distância entre a compreensão do HIV como onipresente e inexorável na carreira moral dos gays e aquela da construção social dessas identidades em torno de atributos pessoais desacreditados ou descreditáveis socialmente, como nos ensinou Goffman (2008). 
Tal perspectiva pode nos oferecer pistas para entender o aumento da incidência da infecção entre jovens na última década em outros termos (KERR et al., 2018; BRASIL, 2019). Trata-se, portanto, de uma forma de acercamento da realidade já consagrada nas ciências sociais, porém em outros campos, como na saúde, abordar o fenômeno dessa maneira possibilita não incorrer em interpretações apressadas. Vêse ganhar corpo, na sociedade, em geral, e entre profissionais e gestores do Sistema Único de Saúde (SUS), em particular, um discurso conservador, culpabilizador e moralizante sobre os jovens e as formas como vivem e exercem suas sexualidades que em muito se assemelha às estratégias proibicionistas e repressivas dos anos iniciais $\mathrm{da}$ epidemia (PERLONGUER, 1985). Ao etnografar um encontro de JVHA, Cunha (2018, p. 308) relatou o brado de um interlocutor que disse: "parem de nos culpar pela infecção!” A antropóloga analisa como esses processos de responsabilização vai, ao mesmo tempo, "gerando novos efeitos biopolíticos e impactos nos contornos identitários de movimentos sociais" (CUNHA, 2018, p. 309) e abrindo caminhos para as estratégias de biomedicalização, a centralidade do "risco" e a produção de corpos tratados e tratáveis, cujos desdobramentos já se fazem sentir, por exemplo, com a implementação da profilaxia pré-exposição (PrEP) no Brasil desde 2017.

Para percorrer a distância entre uma chave explicativa e outra, foi requerido de Franco, ao mesmo tempo, lidar com as inflexóes físicas decorrentes de outras infecçôes secundárias ao HIV, além das emocionais e sociopolíticas pós-diagnóstico. Em menos de um ano, ele foi diagnosticado com sífilis, papiloma vírus humano (HPV) e depressão, o que implicou em dificuldades e agenciamentos, como por exemplo ter realizado uma "autocirurgia".

Eu tive a fase aguda da sífilis e do HPV. Acho que o HPV foi o que mais mexeu comigo, com meus relacionamentos afetivos e com o meu corpo. Eu fiz cirurgia devido ao HPV e tive reincidência. Eu fui invadido cirurgicamente. Tempos depois apareceu novamente uma verruga e eu estava indo fazer intercâmbio fora do país. Comprei bisturi e luvas. Coloquei um espelho no chão. Apontei a câmera do celular para cima com o flash ligado e me autocirurgiei. Isso foi muito complicado. Eu não contei pra ninguém. Entupi-me de algodáo e viajei pra Europa. Quando cheguei ao ponto de fazer isso, vi em que nível a minha cabeça estava.

O sentimento de invasão do corpo parece dizer do lugar que este ocupa na vida do artista. Um lugar que em muito contrasta com aquele das práticas biomédicas. Se na vida profissional o corpo se coloca como linguagem, sujeito, território, jogo de imaginação, etc., de maneira que só fragilmente poderia ser desvinculado da 
existência do ator fora dos palcos (ROMANO, 2005), no mundo biomédico, no qual Franco acabara de adentrar como PVHA, o corpo era representado como separado da pessoa, realidade anatômica, maquinaria ruidosa, um resto (LE BRETON, 2011). Em sua experiência, a produção de pontes entre esses "corpos” foi fundamental na sua construção como "pessoa soropositiva".

Valle (2010) destacou o papel do corpo no processo de construção da "pessoa soropositiva”. Para o autor, tal processo implica em incorporar e aprender "práticas terapêuticas de consumo sistemático e controlado de remédios, de leitura dos sintomas da doença e dos tratamentos sobre o corpo, dos procedimentos clínicos e tecnológicos de exames e terapias que devem ser efetuados regularmente" (VALLE, 2010, p. 43). Na experiência de Franco, essa incorporação e aprendizagem não se deram de forma desvinculada dos palcos. Essas experiências corporais estavam presentes e deram vida à personagem que Franco interpretou na peça teatral apresentada durante o seminário - uma persona inscrita numa corporeidade emergida dessas pontes entre arte, vírus e biomedicina. Teatralizar a dor, a ponte, a agência para performar a própria vida.

A arte como linguagem política nos permitiu conhecer uma pessoa que situava e delineava suas características a partir de marcadores sociais da diferença ("venho da zona rural, sou bicha, pobre, parda, preta, como queiram me identificar, agora tenho o estigma do HIV e ainda sou artista!"), por meio de linhas (permeáveis), onde a separação entre ficção e realidade era tênue, de maneira que havia fluxos, desejos e devires que a ultrapassavam e se misturavam. A arte estava em seu cotidiano como linguagem, como profissão, como conhecimento, como projeto de ser no mundo, como política e era naquele cotidiano de artista que suas redes foram sendo tecidas, num movimento em que juventude, lugar e universidade 5 se integravam em experimentaçôes e desvelamentos no mundo social gay.

Desde 2016, Franco tem produzido, atuado e dirigido vários espetáculos teatrais e performances sobre HIV/aids. Seus trabalhos eram conhecidos e amplamente divulgados em redes e mídias sociais pelo seu caráter de denúncia do desmonte da política de aids no Brasil e dos processos de estigmatização das PVHA. Essa gramática política guardava relaçôes com a já consagrada presença corporal e performática de ativistas em HIV/aids desde os anos 1980 e 1990, como destacado por Valle (2017b). O autor chama atenção para as sobreposiçôes entre corpo, emoçôes e ativismo como "uma questão crucial para se entender as reelaborações societárias 
pelas quais passam as pessoas com HIV, com reajuste emocional evidente, sobretudo aquelas que se inseriram no ativismo social" (VALLE, 2017b, p. 96).

\section{Ativismo e arte na produção de um "vírus-território"}

No último dia do seminário, em 2017, a programação cultural incluiu uma peça teatral sobre HIV/aids. A plateia estava reunida no solar, ao lado de um corredor que dava acesso ao auditório onde a peça foi apresentada. Enquanto isso, Franco e sua equipe aprontavam os últimos detalhes do espetáculo. De repente, ouvimos sons de campainhas que antecedem os embarques de passageiros nos aeroportos: "Atenção senhoras e senhores passageiros, vamos iniciar o embarque", disse uma jovem atriz. O espetáculo "Para onde vem, para onde vai, Cida?" era composto por cenas que se passavam durante um voo. Franco dirigia e atuava, juntamente com Helena e Patrício, seus colegas de faculdade, na encenação baseada no teatro épico de Brecht.

Sentamo-nos na plateia conduzidos pelos atores e se iniciou a viagem, um encontro e uma despedida, nos quais eram problematizados: a construção social da aids; o tabu em torno da epidemia; cenas de um cotidiano ordinário; dados epidemiológicos; efeitos colaterais da TARV; campanhas publicitárias e uma série de outros elementos relacionados ao preconceito, à falta de informação, à discriminação e ao estigma do HIV/aids que matam mais que o próprio vírus. O roteiro do espetáculo mobilizava o emaranhado de significados presentes na "linguagem de relaçáo" (GOFFMAN, 2008) que construía o estigma da aids, o que demonstrava a sua permanência e contínua atualização como uma epidemia de significados (TREICHLER, 1987). Ao final da apresentação estávamos todos afetados, com nossos núcleos macios sensibilizados, como apontado na reportagem que abre este artigo.

Encerrados os trabalhos naquela noite, saímos para comemorar o sucesso do evento. Na praça da cidade, sentados ao redor de um banco, Franco e um dos autores deste artigo conversavam e tentavam entender as reaçóes do público ao final do espetáculo. Chegamos à conclusão de que sua performance ganhara outros sentidos ali, inclusive para ele, visto que em uma das mesas redondas do seminário, pela primeira vez, Franco havia falado publicamente sobre sua sorologia.

Além disso, a participação no evento possibilitou que ele conhecesse uma ativista em HIV/aids, membra do Coletivo Loka de Efavirenz ${ }^{6}$, com quem já havia mantido contato pela internet, que o convidou a integrar o referido Coletivo. Sua participaçáo 
na Loka de Efavirenz promoveu o aumento das relaçôes interpessoais e o vínculo com outros ativistas residentes em diferentes regióes do país. Tais experiências foram significativas para ele:

A sensação que eu tive foi de fortalecimento desse lugar de fala, de dizer assim: "sim, eu
tenho HIV e isso não é o maior problema da minha vida, mas é um grande problema", e
"isso não é quem eu sou. Isso é uma parte de alguma trajetória que está sendo construída
e a gente precisa problematizar e falar sobre". O evento foi incrível porque era uma galera
muito diversa, da universidade, que trabalhava no hospital.

A inserção de Franco no ativismo possibilitou o diálogo com pares, a troca de informaçóes e experiências, ao passo que tensionava o viver com HIV/aids como uma questão pública, o que fortalecia a análise crítica da epidemia: "então a minha percepçáo mudou completamente, porque eu comecei a humanizar o vírus. Comecei a parar de olhar só o sentido biológico da coisa e a pensar como ele muda no corpo, na cultura”. Humanizar o vírus significava compreendê-lo em contexto e como uma construção social, o que dialoga com a perspectiva de Treichler (1987, p. 32) para quem "os processos de significação não são servos dos 'fatos'; antes, 'os fatos' são um surgimento das práticas significantes do discurso biomédico" e de outros que constituíam as disputas e polissemias discursivas em torno do HIV/aids. Tal compreensão lhe permitiu a produção de redes sociais constituídas em torno de afetos e de solidariedade - marca do movimento social de aids em todo o mundo. Esse engajamento "deu forças para entender que eu não estava sozinho e que podia me ajudar ajudando outras pessoas", isto é, o "ativismo social me ajudou bastante a encarar o HIV na linha de frente".

A atuação política de Franco não teve início no Coletivo Loka de Efavirenz e nas suas peças teatrais. Logo após o diagnóstico, ele criou o grupo "Moçost" na rede social WhatsApp que reunia rapazes potiguares dada a necessidade de "falar sobre e não ter com quem falar”. Com a publicização de sua sorologia em 2017, passou a compor outras redes e grupos nacionais de ativistas em HIV/aids ${ }^{7}$. A esse respeito Franco resumiu: "essa coisa da relação afetiva [família e amigos] e de um motivo para lutar foram estratégias de sobrevivência também, sabe? Como resistir a isso? Eu achei que falando sobre isso seria uma boa forma!" Porém, "falar sobre" não significava, apenas, se remeter à sua experiência comezinha e atual com o HIV/aids. No espetáculo apresentado ao final do seminário, por exemplo, essa experiência individual se emaranhava numa estética e numa narrativa plenas em memórias de 
dor e de sofrimentos, próprias dos anos iniciais da epidemia: as cançôes de Cazuza, as reportagens sensacionalistas, as mortes feitas tragédia e pânico, a zidovudina (AZT), a liberalização sexual dos anos 1960-70, o voo como metáfora, etc.

Entendemos que essa produção estética e narratividade dialogam com aquilo que Valle (2018) denominou de "tradição de conhecimento ativista", visto que integram memórias, testemunhos e histórias, por meio de uma expertise que se baseia numa aproximação entre passado e presente que compóem uma mesma história.

\footnotetext{
"Trata-se de um conhecimento elaborado a fim de subsidiar, interpretar e dar sentido às açôes, à finalidade e às decisóes feitas por pessoas de uma determinada organizaçáo sociopolítica: cartas de princípios, estatutos, boletins e relatórios, material de prevenção contra a infeção HIV (cartilhas de sexo seguro), documentação escrita e audiovisual, cartazes, mas também cultura material diversa, além de imagens, fotografias etc." (VALLE, 2018, p. 159).
}

Na experiência de Franco como um JVHA, essa "tradição de conhecimento ativista" lhe colocava em contato com memórias e histórias da luta contra a aids por meio do consumo dos materiais, documentos e produção cultural, uma vez que não viveu as décadas iniciais da epidemia. Ao mesmo tempo, nos permite compreender as relaçóes de continuidade e de rupturas entre o movimento social de aids a partir de uma perspectiva geracional. Um elo entre essas geraçôes de ativistas pode ser observado na gramática emocional e política presente na concepção do ativismo como uma "estratégia de sobrevivência". Sobrevivência aqui significa mais que "estar viva e bem em termos de saúde", pois "mobiliza igualmente, para muitas pessoas, um trabalho emocional da memória, que se faz por meio de uma visada reflexiva sobre o passado, diante do que foi vivido, das pessoas com as quais se conviveu e em relação a muitas que já não estão mais presentes" (VALLE, 2018, p. 173).

$\mathrm{Na}$ sua tessitura como "pessoa soropositiva", tornou-se referência em HIV/aids entre pessoas próximas, permitindo performar novas identidades, corporeidades e territórios:

Eu virei meio que um guru do HIV e do sexo entre os meus amigos. Qualquer dúvida que eles tenham, vêm tirar comigo. Mas tem muita coisa que eu estou descobrindo junto com eles. Eu virei um lugar de acesso. É engraçado, pois depois que eu descobri que tinha HIV e contei para esses amigos, sete deles usaram PEP [Profilaxia Pós-Exposição]. Eu não sabia da $\mathrm{PEP}$ em todas as minhas situaçôes de risco. Eu nunca ouvi falar de PEP e esses meus amigos só ouviram falar disso através de mim. Hoje estão todos sem diagnóstico positivo e me agradecem por ter possibilitado o acesso a essa informaçáo. E o curioso também é que alguns dos que tomaram a PEP tiveram os mesmos efeitos colaterais que eu. Então, eles entenderam, na pele, o que é viver com o que eu vivo todo dia tendo esses efeitos colaterais e, ainda mais, tendo o vírus no sangue, coisa que eles não têm. Mas sem- 
pre que um amigo vai fazer exame [testagem para HIV], o coração aperta! Então é isso, eu virei meio que um cuidador.

Assim, estar inserido no ativismo possibilitou uma mudança na forma como Franco vivia com o HIV/aids, pois tal temática passou a ser uma pauta política (PELÚCIO, 2007) que compunha sua vida, como também de uma coletividade da qual ele fazia parte. Nesse sentido, ao afirmar que se tornou um "guru do HIV e do sexo" e um "lugar de acesso", Franco apontava para sua construção como "pessoa soropositiva” não a partir de processos de pedagogização (CUNHA, 2012; 2018) ou de empoderamento de jovens (ZAGO; SANTOS, 2013) orquestrados pela política de saúde, cujo objetivo é incentivar um tipo de "protagonismo" e de "jovem multiplicador" calcado na responsabilização. Pelo contrário, esse "guru” se constitui por meio do compartilhamento de saberes, de experiências de alteridade e de uma perspectiva sobre o vírus sempre contextualizada e crítica. Não mais o "HIV-profecia" ganha relevo - embora o tempo todo lembrado - mas o "HIV-território", porque "lugar de acesso", de cuidados, de encontros, de trocas, de produção de identidades a partir de alteridades.

Se retomarmos a matéria que abriu este artigo, poderemos alargar as possibilidades de leitura, uma vez que a história de Franco nos oferece um olhar mais adensado para as relaçóes entre ativismo e arte. Tanto para os entrevistados do repórter quanto para o nosso interlocutor, a produçáo artística como linguagem política de ativistas em HIV/aids constrói e põe em operação narrativas positHIVas sobre a epidemia, as pessoas que vivem com o vírus ou estão doentes de aids, as políticas de saúde, as relaçôes sociais, etc. Narrativas PositHIVas, um neologismo por aglutinação e analogia, busca circunscrever um conjunto de produçóes culturais, científicas, políticas e sociais que tomam como centro de gravidade o viver com o HIV/aids a partir da experiência de seus autores como PVHA ou de coletividades, sempre produzidas e protagonizadas por PVHA. Analisar a história de Franco tendo como eixo as relaçóes entre ativismo e arte nos colocou diante da produção de uma sociologia das ausências (SANTOS, 2002).

Estando a epidemia de HIV/aids, desde sua emergência, no centro de uma cruzada moral endereçada aos sujeitos, identidades e sexualidades tidas como dissidentes, bem como os sistemáticos processos de discriminação, estigmatização e marginalização das pessoas afetadas (PATTON, 1990; DANIEL; PARKER, 1991; 
WATNEY, 1997), produzir arte como forma de ativismo implica em se colocar, como afirmou Franco, na "linha de frente" da luta contra as políticas de invisibilidade das PVHA. Em tempos de restrição discursiva sobre HIV/aids e da sua modelação como uma "doença segredo" (INÁCIO, 2016), a produção dessas narrativas positHIVas assinala não só os processos sociais mais amplos que vulnerabilizam, apagam e silenciam, mas, também, estabelece outros lugares e agências para as PVHA em suas relações - quase sempre conflituosas - com os saberes e práticas biomédicas que buscam colonizar suas vidas e seus corpos.

Por meio dessas narrativas positHIVas instauram-se ecologias que póem em operação a sociologia das ausências, cujo objetivo é ampliar o presente, a realidade, o que significa incluir "as realidades ausentes por via do silenciamento, da supressão e da marginalização, isto é, as realidades que são activamente produzidas como não existentes" (SANTOS, 2002, p. 253). Em nossa análise, essas ecologias se apresentaram na maneira como Franco performava o ativismo em HIV/aids ao dar relevo aos conhecimentos forjados na experiência das PVHA com o adoecimento em diálogo com saberes biomédicos (ecologia de saberes); nos alinhavos e atualizaçôes de memórias, histórias e testemunhos sobre pessoas e a epidemia, contrastando com a linearidade da historiografia oficial (ecologia das temporalidades); na assunção das diferenças sociais e na maneira como estas modelam sujeitos e identidades em detrimento das classificaçôes e hierarquizaçôes sociais hegemônicas (ecologia de reconhecimentos); na produção artística que integra escalas locais, regionais e global sem perder de vista especificidades e diferenças (ecologia das trans-escalas) e na gramática organizacional dos movimentos sociais, coletivos e redes que buscam romper com a ortodoxia capitalista, patriarcal e normatizada (ecologia de produtividade).

\section{Considerações Finais}

Nesteartigo buscamos compreender os significados do engajamento no movimento social de aids e suas inflexóes na produção do JVHA, a partir da experiência de Franco. A perspectiva socioantropológica associada à análise contextual, relacional e particular do estudo de caso qualitativo permitiu interpretar, a partir do material de campo, o processo de construção da pessoa soropositiva. Na experiência de Franco tal processo se deu no agenciamento de produçôes artísticas como uma linguagem política do ativismo em HIV/aids. 
Destacamos como a partir desse engajamento, nosso interlocutor transformou um "vírus-profecia" em um "vírus-território", num movimento que integrou, de um lado, memória, história, testemunho e, de outro, corpo, performance, emoção, territórios. Desse movimento, resultou narrativas positHIVas, como uma sociologia das ausências, cujo objetivo é recolocar em cena discursos, sujeitos, agências e formas de vida que se contrapóem à cruzada moral que há décadas se realiza contra as PVHA no Brasil e no mundo.

\section{Referências}

ARAUJO, W. J. et al. Percepção de enfermeiros executores de teste rápido em Unidades Básicas de Saúde. Revista Brasileira de Enfermagem, Brasília, v. 71, p. 631-636, 2018. Supl. 1.

BAŠKARADA, S. Qualitative Case Study Guidelines. The Qualitative Report, Orlando, v. 19, n. 40, p. 1-18, 2014.

BRASIL. Boletim Epidemiológico - HIVIAIDS. Brasília: Ministério da Saúde, 2019.

CORTEZ, L. C. A. "Ou eu luto, ou eu morro": ativismo em HIVlaids e processos de subjetivação na experiência da Coletiva Loka de Efavirenz. 2019. 121f. Dissertação (Mestrado em Saúde Coletiva) - Faculdade de Ciências da Saúde do Trairi, Universidade Federal do Rio Grande do Norte, Santa Cruz, 2019.

CUNHA, C. C. Os muitos reveses de uma "sexualidade soropositiva": o caso dos jovens vivendo com HIV / AIDS. Sexualidad, Salud y Sociedad - Revista Latino-americana, Rio de Janeiro, n. 10, p. 70-99, 2012.

CUNHA, C. C. Configuraçóes e reconfiguraçóes do movimento de jovens vivendo com HIV/AIDS no Brasil: Identidades e prevençôes em jogo. Sexualidad, Salud y Sociedad - Revista Latino-americana, Rio de Janeiro, n. 29, p. 294-312, 2018.

DANIEL, H.; PARKER, R. AIDS, a terceira epidemia: ensaios e tentativas. São Paulo: Iglu Editora, 1991.

FACCHINI, R. Sopa de letrinhas? Movimento homossexual e produção de identidades coletivas nos anos 90. Rio de Janeiro: Garamond, 2005.

FLICK, U. Introdução à pesquisa qualitativa. 3a ed. Porto Alegre: Artmed, 2009.

GALVÃO, J. AIDS no Brasil: a agenda de construção de uma epidemia. São Paulo: Editora 34, 2000.

GOFFMAN, E. Estigma: notas sobre a manipulação da identidade deteriorada. 4. ed. Rio de Janeiro: LTC, 2008.

INÁCIO, E. Carga zerada: HIV/AIDS, discurso, desgaste, cultura. Revista Via Atlântica, São Paulo, n. 29, p. 479-505, 2016. 
KERR, L., et al. HIV prevalence among men who have sex with men in Brazil - results of the 2nd national survey using respondent-driven sampling. Medicine, Baltimore, v. 97, n. 1S, p. S9-S15, 2018. Suppl 1.

LE BRETON, D. As fontes de uma representação moderna do corpo: o homem anatomizado. In: LE BRETON, D. Antropologia do corpo e modernidade. Petrópolis: Vozes, 2011. p. 43-96.

MISKOLCI, R. Pânicos morais e controle social: reflexôes sobre o casamento gay. Cadernos Pagu, Campinas, n. 28, p. 101-128, 2007.

NELVO, R. V. Jovens personagens do HIV/aids: reflexóes sobre a "pessoa” emotiva. CSOnline - Revista Eletrônica de Ciências Sociais, Juíz de Fora, n. 27, p. 5-26, 2018.

PATTON, C. Inventing AIDS. New York: Routledge, 1990.

PELUCIO, L. Ativismo soropositivo: a politização da aids. Ilha - Revista de Antropologia, Florianópolis, v. 9, n. 1,2, p. 119-141, 2007.

PELUCIO, L.; MISKOLCI, R. A prevenção do desvio: o dispositivo da aids e a repatologizaçáo das sexualidades dissidentes. Sexualidad, Salud y Sociedad - Revista Latino-americana, Rio de Janeiro, n. 1, p. 125-157, 2009.

PERLONGHER, N. AIDS: disciplinar os poros e as paixóes. Lua Nova: Revista de Cultura e Política, São Paulo, v. 2, n. 3, p. 35-37, 1985.

ROMANO, L. O papel do corpo no corpo do ator de Sônia Machado de Azevedo. Sala Preta, São Paulo, v. 5, p. 249-252, 2005.

SANTOS, B. S. Para uma sociologia das ausências e uma sociologia das emergências. Revista Critica de Ciências Sociais, Coimbra, n. 63, p. 237-280, 2002.

SCOTT, J. W. A invisibilidade da experiência. Projeto História: Revista do Programa de Estudos Pós-Graduados de História, v. 16, p. 297-325, 1998.

SEFFNER, F.; PARKER, R. Desperdício da experiência e precarização da vida: momento político contemporâneo da resposta brasileira à aids. Interface - Comunicação, Saúde, Educação, Botucatu, n. 20, v. 57, p. 293-304, 2016.

SERRANO BLASCO, J. Estudio de casos. In: AGUIRRE BAZTÁN, Á. Etnografía: metodología cualitativa en la investigación sociocultural. Ciudad de México: Alfaomega; Marcombo; 1997. p. 203-8.

SILVA, C. L. C. Ativismo, ajuda-mútua e assistência: a atuação das organizaçôes nãogovernamentais na luta contra AIDS. 1999. 362f. Tese (Doutorado em Ciências Humanas Sociologia) - Universidade Federal do Rio de Janeiro, Rio de Janeiro, 1999.

SIMOES, J. A. Geraçôes, mudanças e continuidades na experiência social da homossexualidade masculina e epidemia de HIV-Aids. Sexualidad, Salud y Sociedad - Revista Latino-americana, Rio de Janeiro, n. 29, p. 313-339, 2018. 
STAKE, R. E. Case Studies. In: DENZIN, N.; LINCOLN, Y. (org.). The handbook of qualitative research. 2. ed. London: Sage Publications, 2000. p. 435-454.

TREICHLER, P. A. AIDS, homophobia and biomedical discourses: an epidemic of signification. October, Cambridge, vol. 43, p. 31-70, 1987.

VALLE, C. G. O. Apropriações, conflitos e negociaçôes de gênero, sexualidade e sorologia: etnografando situaçóes e performances no mundo social do HIV/AIDS (Rio de Janeiro). Revista de Antropologia USP, São Paulo, v. 51, n. 2, p. 651-698, 2008.

VALLE, C. G. O. Corpo, doença e biomedicina: uma análise antropológica de práticas corporais e de tratamento entre pessoas com HIV/AIDS. Vivência: Revista de Antropologia, Natal, n. 35, p. 33-51, 2010.

VALLE, C. G. O. Política, identidades e cidadania: a sociogênese e os impasses do ativismo biossocial do HIV/aids no Brasil. In: SACRAMENTO, O.; RIBEIRO, F.B. (orgs.). Planeta SIDA: Diversidade, política e respostas sociais. Ribeirão: Ediçôes Humu, 2016. p. 83-103.

VALLE, C. G. O. Mediadores e experts biossociais: saúde, ativismo e criminalização da infecção do HIV. In: TEIXEIRA, C. C.; VALLE, C.G.; NEVES, R. C. (orgs). Saúde, mediação e mediadores. Brasília: ABA Publicaçóes; Natal: EDUFRN; 2017a. p. 26-75.

VALLE, C. G. O. Afirmando-se a vida, constrói-se o tempo: experiência, emoções e ativismo político contra a AIDS. Interseçôes: Revista de Estudos Interdisciplinares, Rio de Janeiro, v. 19, n. 1, p. 77-105, 2017 b.

VALLE, C. G. O. Memórias, histórias e linguagens da dor e da luta no ativismo brasileiro de HIV/Aids. Sexualidad, Salud y Sociedad - Revista Latino-americana, Rio de Janeiro, n. 30, p. 153-182, 2018.

WATNEY, S. Policing desire: pornography, aids and the media. 3. ed. Londres: Cassell, 1997.

WILLIAMS, G. The genesis of chronic illness: narrative re-construction. Sociology of Health \& Illness, London, v. 6, n. 2, p. 175-200, 1984.

ZAGO, L. F.; SANTOS, L. H. S. Os limites do conceito de empoderamento na prevenção ao HIV/Aids entre jovens gays e bissexuais no Brasil. Physis: Revista de Saúde Coletiva, v. 23, n. 3, p. 681-701, 2013.

\section{Notas}

${ }^{1}$ Disponível em: https://revistatrip.uol.com.br/tpm/ativistas-soropositivos-usam-a-arte-para-combater-o-preconceito-em-torno-do-hiv Acesso em 13 dez 2019.

${ }^{2}$ Disponível em: https://www.pliniomarcos.com/popup/livros-oator.htm Acesso em 13 dez 2019.

${ }^{3}$ Franco preferiu não manter o anonimato sobre o seu verdadeiro nome, o que é comum em pesquisas com ativistas. Para outras pessoas citadas no texto mantivemos o critério do anonimato, de modo que seus nomes foram trocados. 
${ }^{4}$ No serviço de saúde onde Franco fazia tratamento havia um cartaz com o telefone de uma pessoa e a frase "precisa de ajuda? Fale comigo". Tempos depois Franco resolveu enviar uma mensagem pelo What$s A p p$ para conversar. O homem com quem conversou vivia com HIV/aids há mais de 20 anos. Entre eles foi-se construindo uma relaçáo de pai e filho. Não demorou para Franco ser convidado a morar em sua casa e, com isso, ganhou um irmão, filho de seu novo pai. No texto distinguimos quando Franco se refere à família biológica e à família adotiva.

${ }^{5}$ Franco faz parte de uma geração de jovens brasileiros que vêm tendo acesso ao ensino superior público em decorrência de reformas e ampliações estruturais na rede pública de ensino básico e superior. No Rio Grande do Norte, a ampliação do número de Institutos Federais de Educação, Ciência e Tecnologia - popularmente chamados IF - é um fenômeno que vem mudando a "cara" das universidades públicas locais, uma vez que veio atrelada ao aumento de vagas, de criaçáo de novos campi e cursos nas instituiçốes de ensino superior. Além disso, destaca-se a implementação de açôes afirmativas (as "cotas") para estudantes egressos de escolas públicas, de classe social popular e aquelas voltadas a grupos étnico-raciais. Tais fenômenos são resultados da política educacional dos governos de Luiz Inácio Lula da Silva (2003-2010) e Dilma Rousseff (2011-2016, o último mandato foi interrompido por um golpe institucional), com destaque para o Programa de Apoio a Planos de Reestruturação e Expansão das Universidades Federais (Reuni).

${ }^{6}$ O Coletivo Loka de Efavirenz foi criado em 2016 por um grupo de JVHA de várias cidades e estados brasileiros inicialmente com atuação numa página no Facebook, depois ampliada para outros contextos off-line. O Coletivo se caracteriza pela maneira como "usam proveitosamente os recursos de comunicação propiciados pela internet e falam de si mesmas de maneira afirmativa, expóem suas histórias de convívio com o HIV, sua luta cotidiana contra a discriminação vivenciada na família, nas relaçôes afetivas, na escola, no trabalho, na esfera pública, como também buscam traçar pontes com as associaçóes e as lideranças estabelecidas há mais tempo" (SIMÓES, 2018, p. 334). A etnografia de Cortez (2019) é uma referência pioneira no campo das ciências sociais e humanas em saúde.

${ }^{7}$ Com destaque para a Rede Nacional de Jovens Vivendo com HIV/aids (RNJVHA), a Rede Nacional de Pessoas Vivendo com HIV e Aids (RNP+), Coletivo Loka de Efavirenz e a Rede de Adolescentes e Jovens Vivendo com HIV/AIDS no Estado do Rio Grande do Norte (Rede ElefantHIV). 


\section{Abstract}

From "HIV-prophecy" to "HIV-territory": a case study about young people, subjectivity, and HIVIAIDS activism

This article addresses the individual and collective initiatives of young activists in HIV / AIDS and their consequences in the production of subjectivity. The objective was to understand the meanings of the engagement in the social movement of AIDS and its inflections in the production of young people living with HIV/aids, from the experience of an informant. This case study is part of an ethnography about experiences of people living with HIV/aids who lives in the countryside of Brazilian Northeast, made with 17 persons diagnosed more than a year ago. Two reasons guided the selection of the case: being young with an experience built around axes of differentiation and self-enunciation; and for having shown insertion as an activist. Information was gathered using participant observation, and semi-structured interviews. Through contextual, integrated and relational analysis, art as the political language of HIV/aids activism has posed the potential to transform a "virus-prophecy", a curse that lurks gay men, into a "virus-territory" as a place of access to health care, affections, exchanges and experiences of otherness. Finally, was highlight how the relationship between art and activism in HIV/aids allows the production of positHIVe narratives that stand as a Sociology of Absences.

> Keywords: HIV/aids; illness experience; political activism; art; sexual and gender minorities; generation; subjectivity. 


\section{ERRATA}

No artigo "DO "HIV-PROFECIA" AO "HIV-TERRITÓRIO": UM ESTUDO DE CASO SOBRE JUVENTUDE, SUBJETIVIDADE E ATIVISMO EM HIV/ AIDS", com número de DOI: http://dx.doi.org/10.1590/S0103-73312021310406 publicado no periódico Physis: Revista de Saúde Coletiva, v. 31, n. 4, e310406, na página 1, erro de nome de autor:

ONDE SE LÊ:

Lumera Cristina de Assunção Cortez

LEIA-SE:

Lumena Cristina de Assunção Cortez 